\title{
DESCONSIDERAÇÃO DA PERSONALIDADE JURÍDICA NA FALÊNCIA
}

\author{
Mirian Gomes Canavarro Batista
}

RESUMO: O presente trabalho dedica-se ao estudo da Desconsideração da Personalidade Jurídica, ou disregarddoctrine e sua aplicação na Lei 11.101/05. Focamos a análise na temática da personalidade jurídica, com a sua característica limitação patrimonial, de cunho essencial para desenvolver e estimular a atividade econômica.

Palavras-chave: Desconsideração da personalidade jurídica. DisregardDoctrine. História da Desconsideração da Personalidade Jurídica. PersonalidadeJurídica. Responsabilidade dos Sócios.Falência.

ABSTRACT: This work is dedicated to the study of Disregard of Legal Personality, or disregard doctrine and its application in Law 11.101/05. We focus the analysis on the subject of legal personality, with its characteristic balance limitation, essential nature to develop and stimulate economic activity.

Keywords:Theory of disregard of legal entity. Disregard Doctrine. Disregard History of Legal Personality. Legal Personality. Liability of Members.Bankruptcy.

\section{INTRODUÇÃO}

O objetivo deste trabalho é a análise da responsabilidade pessoal dos sócios (art. 81 da Lei de Recuperação e Falência), juntamente com a apuração da responsabilidade pessoal dos sócios de responsabilidade limitada, os administradores e controladores da sociedade falida (Art. 82 da Lei de Recuperação e Falências), bem como, ainda, a aplicação do instituto da desconsideração da personalidade jurídica na Lei 11.101/05.

\section{PERSONALIDADE JURÍDICA}

Ao contrário de outros países,no Brasil, a personalização da sociedade não está unicamente vinculada à limitação da responsabilidade de seus integrantes ${ }^{1}$, isso porque temos sociedades personalizadas em que os sócios respondem pelas obrigações sociais ilimitadamente, bem como, outras em que os sócios respondem de forma limitada. 
De toda forma, independente da responsabilidade,as sociedades são sempre personalizadas, ou seja, são pessoas distintas dos sócios, com direito e obrigações próprias. Como bem explica Rubens Requião: “A sociedade transforma-se em novo ser, estranho à individualidade das pessoas que participam de sua constituição, dominando um patrimônio próprio, possuidor de órgão de deliberação e execução que dita e faz

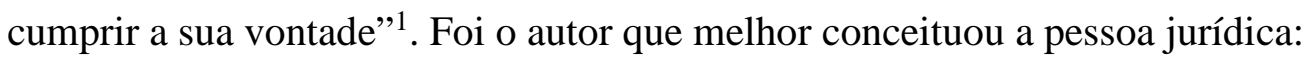

\begin{abstract}
Entende-se por pessoa jurídica o ente incorpóreo que, como as pessoas físicas, pode ser sujeito de direitos. Não se confundem, assim, as pessoas jurídicas com as pessoas físicas que deram lugar ao seu nascimento; pelo contrário, delas se distanciam, adquirindo patrimônio autônomo e exercendo direitos em nome próprio. Por tal razão, as pessoas jurídicas têm nome particular, como as pessoas físicas, domicílio e nacionalidade; podem estar em juízo, como autoras ou como rés, sem que isso se reflita na pessoa daqueles que a constituíram. Finalmente, têm vida autônoma, muitas vezes superior à das pessoas que as formaram; em alguns casos, a mudança de estado dessas pessoas não se reflete na estrutura das pessoas jurídicas, podendo, assim, variar as pessoas físicas que lhe deram origem, sem que esse fato incida no seu organismo. É o que acontece com as sociedades institucionais ou de capitais, cujos sócios podem mudar de estado ou ser substituídos sem que se altere a estrutura social. ${ }^{2}($ REQUIÃO, 1998)
\end{abstract}

Aproveitando as nuances etéreas do conceito acima, partimos para a análise de outro tema ainda não harmonizado: a natureza da personalidade jurídica.

Diante de tantas discussões jurídicas e dogmáticasem torno do tema,Savigny inaugurou uma teoria acerca da natureza da Personalidade Jurídica, através de sua Teoria da Ficção. Defendia o jurista que somente a pessoa natural teria capacidade de ser sujeito de direitos e deveres, por isso, admitir a existência de um ente personificado que não fosse humano, seria viável somente através de uma ficção jurídica, ou seja, para fundar a teoria tradicional sobre as pessoas jurídicas, Savigny recorreu a um instrumento típico do formalismo legal que é a ficção jurídica. Quando ele disse que a lei positiva tem o poder de estender a capacidade legal para outros além dos homens, criando entidades jurídicas artificiais, ele enunciou essencialmente um cânone hermenêutico acolhido pela doutrina jurídica, que professava unicamente ao direito positivo. Nesse contexto, a fidelidade à lei positiva exigiria também a fidelidade à ficção nela incorporada, bem como garantir que tais ficções pretendidas pelo legislador seriam vinculativas para os intérpretes da lei, fazendo com que eles se obrigassem a equacionar a ficção à realidade quando assim fosse exigido por lei.

\footnotetext{
${ }^{1}$ REQUIÃO, Rubens, Curso de Direito Comercial, 1 volume, São Paulo:Saraiva, 1993. p. 471

${ }^{2}$ REQUIÃO, Rubens. Curso de Direito Comercial. São Paulo: Forense, 1998. p. 204.
} 
A partir dos estudos de Savigny, desenvolveram-se várias teorias que tinham por base o mesmo raciocínio do autor, mas com estudos mais alargados e diferenciais em alguns aspectos. Em contraposição à teoria da ficção, depois de muitas idas e vindas, surge a doutrina conhecida como Teoria do Realismo, adotada pelo Código Civil de 2002 e, atualmente, dominante, mas, nem por isso, menos complicada.

Podemos sintetizar, numa estratégia para encerrar a embate, que o sentido da personalidade jurídica éa autonomia patrimonial. Como lembra Fábio Ulhôa Coelho, ao finalizar, de forma sintética, o debate: "No final, o que está em jogo, nas questões relativas a pessoas jurídicas, é sempre a distribuição de bens entre indivíduos: quem usufrui o quê3." Continua ratificando o conceito de que a natureza da pessoa jurídica é uma ideia, conhecida pelos membros da comunidade jurídica a fim de superar conflitos e interesses.

Resta claro que o surgimento da pessoa jurídica ${ }^{4}$ resultou de uma necessidade pungente de segurança nos negócios que, com o passar dos anos, foram tomando uma forma mais elaborada e coletiva. Caio Mário da Silva Pereira bem explica a situação5:

COELHO, Fabio Ulhoa, Curso de Direito Comercial.v.2, p. 27.

${ }^{4}$ Durante os estudos preliminares para a redação deste artigo, tive a honra de me deparar com o parecer do Dr. Paulo Fernando Campos Salles de Toledo que trouxe à baila da minha ignorância a Fábula da Pessoa Jurídica (GALGANO, in - RovesciodelDiritto, denominada "La Favola Della Persona Giuridica." Durante o decorrer de toda a escrita, uma frase introdutória ao tema ficou tatuada na minha memória:

"A personalidade jurídica, esta criação do gênio humano que, de certo modo, o equipara ao Criador, volta-se, às vezes, por artes do próprio homem, contra aquele que a gerou."

A fábula tem como personagens principais o Criador, o homem e a pessoa jurídica, figurando como personagens secundários Savigny, Gierke, Kelsen, Ascarelli, e, também, não poderia faltar, o maligno. De início, já destaca a soberba do homem, pois, se Deus criou o homem à sua imagem e semelhança, este, na tentativa de se equiparar ao Criador, cria, à sua imagem e semelhança, a pessoa jurídica, dando-lhe uma assembleia que é seu cérebro e os órgãos de administração, que se equiparam aos órgãos humanos, olhos, orelhas e boca. Se Deus presenteou o homem com a mulher, o homem concebeu a pessoa jurídica (um ente que se reproduz). Em determinado momento, porém, o homem consegue superar quem o criou, afinal a pessoa jurídica pode se imortalizar, com a possibilidade do surgimento de nova pessoa jurídica pela soma de duas ou mais anteriores,através dos processos de fusão ou incorporação e muitas outras possibilidades societárias, colocando que a criatividade do homem pôs em cheque a do Criador.

A fábula, a soberba da criatura acaba por enciumar o Criador, que, decidindo impor castigo aos homens, encarrega o Papa Inocêncio IV de "elaborar teoria destinada a convencer os homens de que a pessoa jurídica nada mais é do que uma ficção; depois incumbe a Bartolo diSassoferrato de convencer os homens que a pessoa jurídica "vereetproprie non est persona"; segue-o Baldo DegliUbaldi, que completa o ensinamento afirmando que pessoas são apenas os homens, não só quando agem individualmente, mas ainda que agindo coletivamente ("uti singuli, uti universi"). Com a pregação e o assentamento destas ideias, a pessoa jurídica acaba ficando esquecida por séculos até a chegada do iluminismo. Enfim, ratificam a existência das pessoas jurídicas como sujeitos fictícios, criados pelo legislador, diz Savigny; na outra ponta Gierke sustenta tratarem-se de verdadeiras unidades sociais vivas. No calor do debate, a divina se manifesta, pois, desvirtuados pelo maligno, os homens são cruéis e tendo criado a pessoa jurídica à sua imagem, aplicam-lhe a mesma crueldade usada contra seus semelhantes. Vejam-se os exemplos da Alemanha nazista ou nos Estados Unidos onde discutiu-se a possibilidade de compra de uma gleba de terras em um lugar onde não se admitiam pessoas de cor, por uma sociedade organizada por

http://revistasapereaude.org/index.php/edicoes/ano-5-volume-1-agosto-2016

D.O.I: 10.20523/sapereaude-ano5-vol-1-pg-77-95 
A necessidade da conjugação de esforços de vários indivíduos para a consecução de objetivos comuns ou de interesse social, ao mesmo passo que aconselham e estimulam a sua agregação e polarização de suas atividades, sugerem ao direito equiparar à própria pessoa humana a certos agrupamentos de indivíduos e certas destinações patrimoniais e lhe aconselham atribuir personalidade e capacidade aos entes abstratosassim gerados.(PEREIRA, 2000)

No desenvolvimento do presente trabalho,interessa-NOS aprofundar sobre os efeitos da personalização, Isso porque, quando definimos a sociedade empresária como pessoa jurídica,criamos, por conseguinte,direitos e obrigações ao sujeito de direito nela contida. Afinal, é justamente a separação entre a pessoa jurídica e seus sócios que se alicerça o princípio da autonomia patrimonial, ou seja, os bens, direitos e obrigações da sociedade, enquanto a pessoa jurídica não se confunde com os dos seus sócios.De certo modo uma das principais vantagens da pessoa jurídica é a limitação de sua responsabilidade.

Fábio Ulhoa Coelho leciona a respeito:

Em sendo assim, pelas obrigações da pessoa jurídica responde, em regra, apenas o patrimônio. É, em geral, incabível a responsabilização do membro da pessoa jurídica por obrigação que não é dele, mas dela. O credor doente moral (sociedade civil ou comercial, associação ou fundação) não pode, em princípio, pretender a satisfação de seu crédito no patrimônio individual de membro da entidade, mesmo em se tratando da pessoa que a representa no negócio ou na ação judicial, já que são sujeitos de direito distintos. Esta regra geral, decorrente do dispositivo de lei acima mencionado, é referida através do princípio da autonomia patrimonial dapessoa jurídica ${ }^{6}$.(COELHO, 1994)

É justamente o princípio da autonomia patrimonial que mitiga os riscos da atividade econômica, afinal, se assim não fosse, a atividade empresária seria pouco atrativa para os investidores, os empresários e a sociedade, que, no final das contas, assumiria o ônus do risco embutido no custo final do produto ou serviço.

negros. E o Criador novamente toma as rédeas da situação e volta-se em favor dos perseguidos pelo nazismo instando Hans Kelsen a repetir literalmente as palavras de Bartolo e de Baldo "E põe na boca de Ascarelli palavras de sabor bíblico: pessoas são apenas os seres nascidos do ventre de uma mulher".

Concluindo a fábula, Galgano indaga como se discutirá, no futuro a pessoa jurídica, admitindo que, a qualquer momento, o homem haveria de lançar novo desafio ao Criador, pois quando o homem atua no papel de jurista, é capaz de demonstrar tudo que quer, contando inclusive para tanto, com franca colaboração do maligno. "Poderíamos, então, imaginar a continuidade da fábula, com o Criador, depois, induzindo o desenvolvimento da teoria da desconsideração da personalidade jurídica como um meio de fazer com que o feitiço se virasse contra o feiticeiro, na medida em que o desvirtuamento da utilização do ente abstrato acabaria se voltando contra o próprio homem, atingindo-o na parte mais sensível de seu corpo: o bolso." Maurício Cunha Peixoto - Palestra proferida no Seminário: O Direito Societário Face ao Novo Código Civil - promovido pela BrainCompany em Belo Horizonte - MG no dia 27/03/2003.

${ }^{5}$ PEREIRA, Caio Mário da Silva. Instituições de Direito Civil, v. I. 19ª ed. Forense. Rio de Janeiro. 2000. p. 185.

${ }^{6}$ COELHO, Fábio Ulhoa. O empresário e os direitos do consumidor. São Paulo, Saraiva,1994, p. 215. 
Conforme nos esclarece autor em comento, a empresa é a atividade e não a pessoa que a explora, assim como empresário - ao contrário do que popularmente se acostumou a designar - não é o sócio, mas a própria sociedade7. Enfim, é a pessoa jurídica que explora a atividade econômica.

A sociedade empresária encontra-se conceituada no artigo 981, caput, do Código Civil8, como sendo a organização proveniente de acordo de duas ou mais pessoas, que pactuam a reunião de capitais e trabalho para um fim lucrativo9.

Ao contrário do que se pode concluir numa análise superficial do artigo 985 do Código Civil, o registro não é condição para que se torne sociedade empresarial quando, na verdade, o que pretende assegurar o referido diploma legal é o reconhecimento da personalidade jurídica que, para exercer regularmente a atividade, deve proceder ao registro da sociedade na Junta Comercial.

Essa formalização traz à vida a pessoa jurídica, com personalidade distinta da pessoa dos sócios e que podem ser classificadas segundo vários critérios. Todavia, a fim de analisar as sociedades empresárias, no instituto da falência, vamos aternosàclassificação quanto à responsabilidade dos sócios, mais precisamente no que tange às sociedades de responsabilidade limitadas (Ltda. e S/A) - tipos mais comuns no Direito Brasileiro.

Merece uma menção sucinta as sociedades com responsabilidades ilimitadas (responsabilidadesilimitadas e solidárias dos sócios relativas às obrigações sociais: sociedade em nome coletivo, sociedades irregulares, sociedades de fato e sociedades tácitas) e as sociedades mistas (quando o contrato social conjuga a responsabilidade ilimitada e solidária de alguns sócios com a responsabilidade limitada de outros: sociedades em comandita simples, sociedade em comandita por ações, sociedades de capital e indústria e sociedades em conta de participação). Breve, por não ser o foco do presente estudo.

\footnotetext{
${ }^{7}$ COELHO, Fábio Ulhoa, Manual de Direito Comercial, 26a edição, São Paulo, Saraiva, 2014.

${ }^{8}$ Art. 981. Celebram contrato de sociedade as pessoas que reciprocamente se obrigam a contribuir, com bens ou serviços, para o exercício de atividade econômica e a partilha, entre si, dos resultados. Parágrafo único. A atividade pode restringir-se à realização de um ou mais negócios determinados.

${ }^{9}$ MARTINS, F.Curso de Direito Comercial. Rio de Janeiro,Forense, 2010.
} 


\section{DESCONSIDERAÇÃO DA PERSONALIDADE JURÍDICA}

A desconsideração da personalidade jurídica existe, na verdade, como uma extensão dos efeitos da falência para atingir os bens dos sócios. Seu objetivo é evitar o abuso do direito e coibir fraude a terceiros de boa-fé.

Nas palavras de Fábio Ulhoa Coelho:

"O objetivo da teoria da desconsideração da personalidade jurídica é exatamente possibilitar a coibição de fraude, sem comprometer o próprio instituto da pessoa jurídica, isto é, sem questionar a regra da separação de sua personalidade e patrimônio em relação a seus membros. Em outros termos, a teoria tem o intuito de preservar a pessoa jurídica e sua autonomia [...], sem deixar ao desabrigo terceiros, vítimas de fraude" ${ }^{10}$.(COELHO, 2010)

Sendo assim, a desconsideração da personalidade jurídica não pode ser vista em oposição ao princípio da autonomia da separação patrimonial da pessoa jurídica, deve, na verdade, ser vista como o instrumento jurídico que serve para fortalecer o princípio da autonomia.

O requisito para a desconsideração da personalidade jurídica é o abuso da personalidade jurídica da empresa que acarrete a confusão patrimonial e o desvio da finalidade da sociedade empresária. É nesse momento que a intervenção do Estado, através do Poder Judiciário, se faz necessária, a fim de verificar se o direito está sendo usado de forma adequada11.

Foi justamente o professor Rubens Requião o pioneiro no assunto, sendoo primeiro jurista brasileiro a tratar da matéria, já que o Código Civil de 1916, ao contrário do que há muito era estudado na Europa, não se dispôs a mencionar o tema:

A disregarddoctrine ${ }^{12}$ aparece como algo mais do que um simples dispositivodo Direito americano de sociedade. É algo que aparece como consequência de uma

\footnotetext{
${ }^{10}$ COELHO, Fábio Ulhoa - Comentários à Lei de Falências e de Recuperação de Empresas. $7^{\mathrm{a}}$ ed. - São Paulo, Saraiva. 2010.

${ }^{11}$ REQUIÃO, Rubens. Abuso de Direito e Fraude Através da Personalidade Jurídica. São Paulo, Revista dos Tribunais, v. 410, p. 14, dezembro, 1969.

${ }^{12}$ No direito americano, essa doutrina recebeu a designação de disregardof legal entity e se converteu em instituto consolidado em matéria de direito de sociedades, a ela devendo recorrer o juiz quando "a sociedade está sendo utilizada fraudulentamente para a violação de um contrato a que se vinculou o acionista majoritário"10, pois, "se um devedor tenta subtrair-se de uma obrigação de fazer ou não fazer o que assumiu, deixando ou fazendo com que uma pessoa jurídica atue em seu lugar, encontramo-nos em face de uma hipótese que equivale à tentativa de burlar a lei com a interposição da pessoa jurídica"11, acrescentando mais: "se pessoa natural contraiu determinada obrigação de fazer ou não fazer, não pode subtrair-se ao seu cumprimento por via de sua ocultação atrás de uma sociedade anônima, pois, se tal ocorrer, o juiz, entendendo que a estrutura formal da pessoa jurídica foi utilizada de maneira abusiva, prescindirá da regra fundamental que estabelece a separação radical entre a sociedade e os sócios, a fim
}

http://revistasapereaude.org/index.php/edicoes/ano-5-volume-1-agosto-2016

D.O.I: 10.20523/sapereaude-ano5-vol-1-pg-77-95 
expressão estrutural da sociedade. E, por isso, em qualquer paísem que se apresente a separação incisiva entre a pessoa jurídica e osmembros que a compõem, se coloca o problema de verificar como se há deenfrentar aqueles casos em que essa radical separação conduz aresultados completamente injustos e contrários ao direito.

Diante do abuso de direito e da fraude no uso da personalidade jurídica, ojuiz brasileiro tem o direito de indagar, em seu livre convencimento, se há deconsagrar a fraude ou o abuso de direito, ou se deva desprezar apersonalidade jurídica, para, penetrando em seu âmago, alcançar aspessoas e bens que dentro dela se escondem para fins ilícitos e abusivos. ${ }^{13}$ (REQUIÃO, 1969)

Por mais que a doutrina recomende cautela na aplicação da teoria, nos últimos anos,os Tribunais foram contemplados com inúmeros pedidos de desconsideração da personalidade jurídica, com pleitos, muitas vezes, em total dissonância com os requisitos fundamentais para aplicação de tão drástica medida: (i) a existência de conduta fraudulenta do agente e (ii) a ocorrência de confusão patrimonial14. Por isso, lembra-nos Fábio Ulhoa que "não é a simples ocorrência de prejuízo ao credor da sociedade quando exaurido o patrimônio dos sócios de responsabilidade não ilimitada, elemento suficiente para a desconsideração da personalidade jurídica da sociedade.”15

Coube então à jurisprudência, acompanhada dos estudos inaugurais de RubensRequião, o desenvolvimento e o aprofundamento da teoria no Direito Civil Brasileiro até que, finalmente, o Código Civil de 2002 consagrou o instituto no artigo $50^{16}$ que dispõe:

\begin{abstract}
"Art. 50. Em caso de abuso da personalidade jurídica, caracterizado pelo desvio de finalidade, ou pela confusão patrimonial, pode o juiz decidir, a requerimento da parte, ou do Ministério Público quando lhe couber intervir no processo, que os efeitos de certas e determinadas relações de obrigações sejam estendidos aos bens particulares dos administradores ou sócios da pessoa jurídica".(CÓDIGO CIVIL, 2002)
\end{abstract}

de que não vingue o resultado contrário ao direito que se tem em vista" 12 , eis que pode ser negada a personalidade da corporation quando o que se pretende, por meio dela, é violar uma obrigação contratual. LOBO, Jorge, Fonte: Revista de Direito $\mathrm{n}^{\mathrm{o}}$ 79-2009, disponível em <http://www.tjrj.jus.br/c/document_library/get_file?uuid=4488a966-f11f-43c5-bd83ee74723c5979\&groupId=10136>

${ }^{13}$ REQUIÃO, Rubens. Abuso de Direito e Fraude Através da Personalidade Jurídica. São Paulo:

Revista dos Tribunais, v. 410, p. 14, dezembro, 1969. - Nesse sentido, também é o ensinamento de Silvio Rodrigues: "Quando se recorrer à ficção da pessoa jurídica para enganar credores, para fugir à incidência da lei ou para proteger um ato desonesto, deve o juiz esquecer a ideia da personalidade jurídica para considerar os seus componentes como pessoas físicas e impedir que, através de subterfúgio, prevaleça o ato fraudulento."

${ }^{14}$ TOLEDO, Paulo Fernando Campos Salles de. A desconsideração da personalidade jurídica na falência. Revista de Direito Mercantil, Industrial, Econômico e Financeiro,134, p.224.

15 COELHO, Fábio Ulhoa. Pessoa jurídica: Conceito e desconsideração. Justitia, São Paulo, v. 137, p. 78.

${ }^{16}$ O Código Civil de 2002 adotou a chamada "Teoria Maior da Desconsideração", ou seja, é exigida a configuração objetiva de tais requisitos para sua aplicação. Assim, não basta apenas a comprovação do estado de insolvência da pessoa jurídica para que os sócios e administradores sejam responsabilizados; é preciso que se comprove a ocorrência do desvio de finalidade ou de confusão patrimonial. 
Gustavo Tepedino, ao comentar o art. 50 do Código Civil, impõe certos requisitos para a aplicação da teoria no caso concreto:

\begin{abstract}
"A respeito da extensão da aplicabilidade da disgarddoctrine a jurisprudência pátria vem se posicionando no sentido em que existem pressupostos específicos, relacionados à fraude e ao abuso de direito de terceiros, que devem ser observados. $\mathrm{O}$ instituto tem por finalidade a proteção de credores lesados e não o benefício da própria pessoa jurídica, e qualquer entendimento contrário a tal premissa implica desvirtuamento da teoria (STJ 4TResp 35. 281). Assim sendo, por se tratar de medida excepcional, não se lhe pode conferir amplitude exacerbada (STJ 4T Resp 347.524). Nessa linha, observa-se que benéficos como da assistência judiciária quando parte por pessoa jurídica, não podem ser a estas estendidos tendo por base a teoria da desconsideração, na medida em que ausentes os pressupostos acima mencionados (TJSP, 7cdp riv; AP civil 181.770- 1). Vale dizer também que a possibilidade de aplicação da disregarddoctrine deve ser demonstrada sob o crivo do devido processo legal (STJ 3T,. Resp. 282.266, ) desta forma, inviabiliza-se a medida em sede de liminar, ainda que implicitamente, já tendo se posicionado a esse respeito o STJ, ao afirmar que tal ocorrência é passível de anulação (STJ, 1T, Ag. Reg. Resp 422.583). O STJ tem admitido a desconsideração da personalidade jurídica também como meio de evitar possíveis fraudes e não tão-somente como meio de recompor dano já causado. Para tanto, devem estar presentes elementos probatórios suficientes a embasar tal conclusão, respeitado o devido processo legal (STJ 3T., ROMS 153.312). Na jornada de direito civil, promovida pelo centro de estudos judiciários do conselho da justiça federal, foi aprovado o enunciado $\mathrm{n}^{\circ} 7$ no sentido de que "só se aplica a desconsideração da personalidade jurídica quando houver a prática de ato irregular, e limitadamente, aos administradores ou sócios que nela hajam incorrido" (ROSADO,Ruy, jornada de direito civil, p. 51)." ${ }^{17}$
\end{abstract}

A jurisprudência confirmou a necessidade de se verificar tais requisitos:

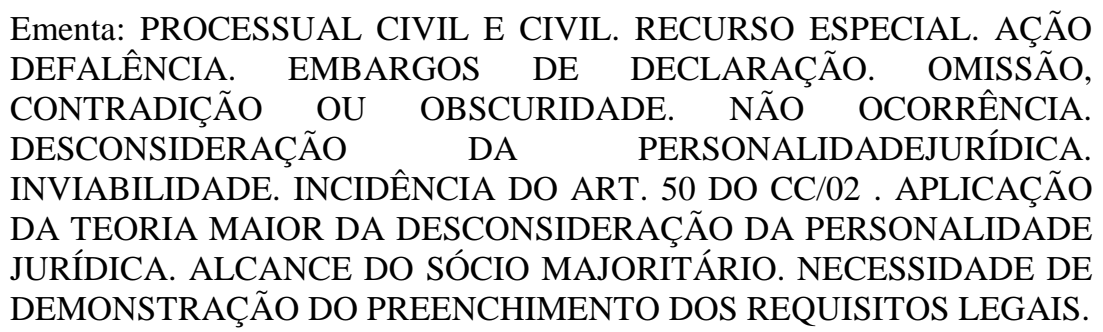
1. Ausentes os vícios do art. 535 do CPC, rejeitam-se os embargos de declaração.

2. A ausência de decisão acerca dos argumentos invocados pelo recorrente em suas razões recursais impede o conhecimento do recurso especial.

3. A regra geral adotada no ordenamento jurídico brasileiro, prevista no art. 50 do CC/02, consagra a Teoria Maior da Desconsideração, tanto na sua vertente subjetiva quanto na objetiva.

4. Salvo em situações excepcionais previstas em leis especiais, somente é possível a desconsideração da personalidade jurídica quando verificado o desvio de finalidade (Teoria Maior Subjetiva da Desconsideração), caracterizado pelo ato intencional dos sócios de fraudar terceiros com o uso abusivo da personalidade jurídica, ou quando evidenciada a confusão patrimonial (Teoria Maior Objetiva da Desconsideração), demonstrada

\footnotetext{
${ }^{17}$ TEPEDINO, Gustavo (Coord.). Problemas de Direito Civil-Constitucional. Rio de Janeiro, Renovar, 2000.p. 102
} 
pela inexistência, no campo dos fatos, de separação entre o patrimônio da pessoa jurídica e os de seus sócios.

5. Os efeitos da desconsideração da personalidade jurídica somente alcançam os sócios participantes da conduta ilícita ou que dela se beneficiaram, ainda que se trate de sócio majoritário ou controlador.

6. Recurso especial parcialmente conhecido e, nesta parte, provido $^{18}$.(STJ, 2013)

Cumpre esclarecer que a aplicação da teoria da desconsideração da personalidade jurídica ${ }^{19}$ não é a extinção da sociedade, mesmo porque, a desconsideração da personalidade jurídica extingue juridicamente o que, na prática, não existia, ou seja, a separação de patrimônio da pessoa jurídica e da física ${ }^{20}$.

\subsection{Sócios ilimitadamente responsáveis}

Voltando ao estudo da separação patrimonial na sociedade empresária, lembramos que os sócios não são totalmente isentos de responsabilidade para com a sociedade, podendo esta ser de dois tipos: responsabilidade limitada e responsabilidade ilimitada. No caso da responsabilidade limitada, o contrato social restringe a responsabilidade dos sócios para com as dívidas da sociedade ao valor de suas contribuições ou à soma do capital social; já na responsabilidade ilimitada os sócios assumem responsabilidade ilimitada e solidária relativamente às obrigações sociais .

\footnotetext{
${ }^{18}$ STJ - RECURSO ESPECIAL REsp 1325663 SP 2012/0024374-2 (STJ) - Data de publicação: $24 / 06 / 2013$

${ }^{19}$ No Brasil, criaram-se duas teorias de desconsideração jurídica: a teoria maior e a menor. Como regra geral, o ordenamento jurídico brasileiro adotou a teoria maior da desconsideração (Código Civil, art. 50; STJ, REsp 970.635, Rel. Min. Nancy Andrighi, 3a T, DJ 10/11/09). Essa teoria prevê que a desconsideração seja precedida de desvio de finalidade da empresa e confusão patrimonial. (STJ, REsp 279.273, Rel. Min. Nancy Andrighi, 3a T, DJ 29/03/04). Fábio Ulhoa ensina que: A teoria maior da desconsideração da personalidade jurídica não é uma teoria contrária à personalização das sociedades empresárias e à sua autonomia em relação aos sócios. Ao contrário, seu objetivo é preservar o instituto, coibindo práticas fraudulentas e abusivas que dele se utilizam. Por sua vez, a teoria menor não exige prova da fraude ou do abuso de direito. Nem é necessária a prova da confusão patrimonial entre os bens da pessoa jurídica e física. Basta, nesse sentido, que o credor demonstre a inexistência de bens da pessoa jurídica, aptos a saldar a dívida.(COELHO, Fábio Ulhoa. Curso de Direito Comercial, v. II. São Paulo: Saraiva, 2003. p. 36).

${ }^{20}$ Fábio Ulhoa explica o assunto: "A doutrina criou, a partir de decisões jurisprudenciais nos EUA, Inglaterra e Alemanha, principalmente, a teoria da desconsideração da pessoa jurídica, pela qual se autoriza o Poder Judiciário a ignorar a autonomia patrimonial da pessoa jurídica, sempre que ela tiver sido utilizada como expediente para a realização de fraude. Ignorando a autonomia patrimonial, será possível responsabilizar-se, direta, pessoal e ilimitadamente, o sócio por obrigação que, originariamente cabia à sociedade."(COELHO, Fábio Ulhoa. Manual de Direito Comercial. 14a Ed. Saraiva. São Paulo. 2003. p. 126).
} 
O sócio com responsabilidade ilimitada responde com o seu patrimônio particular pelas dívidas da sociedade, quebrando a regra geral de separação patrimonial. Ele responde, contudo, de forma subsidiária, ou seja, somente terá seu patrimônio pessoal afetado quando a sociedade não possuir mais bens solventes, conforme disposto no artigo 1.024 do Código Civil.

Tal regra foi quebrada, com a redação dos artigos 81 e 190 da Lei 11.101:

\begin{abstract}
Art. 81 - A decisão que decreta a falência da sociedade com sócios ilimitadamente responsáveis também acarreta a falência destes, que ficam sujeitos aos mesmos efeitos jurídicos produzidos em relação à sociedade falida e, por isso, deverão ser citados para apresentar contestação, se assim o desejarem.

$\S 1^{\circ}$. O disposto no caput deste artigo aplica-se ao sócio que tenha se retirado voluntariamente ou que tenha sido excluído da sociedade, há menos de 2 (dois) anos, quanto às dívidas existentes na data do arquivamento da alteração do contrato, no caso de não terem sido solvidas até a data da decretação da falência.

[...]

Art. 190 - Todas as vezes que esta Lei se referir a devedor ou falido, compreender-se-á que a disposição também se aplica aos sócios ilimitadamente responsáveis. (Lei 11.101, 2005).
\end{abstract}

Os dispositivos supracitados constituem uma das inovações do diploma falimentar vigente, uma vez que, de acordo com a redação do art. $5^{\circ}$ do revogado Decreto-Lei nº 7.661/1945, os sócios, solidária e ilimitadamente responsáveis pelas obrigações sociais, não eram atingidos pela falência da sociedade, ficando, no entanto, sujeitos aos demais efeitos jurídicos que a sentença declaratória produzia em relação à sociedade falida.

Já a Lei de Falências considera falido ${ }^{21}$ não somente o devedor, empresário ou sociedade empresária, mas, ainda, os sócios ilimitadamente responsáveis. Tal inovação tem causado divergência na doutrina, uma vez que alguns autores entendem que as normas são contraditórias com o sistema do Direito Empresarial,isto porque, anteriormente, os sócios com responsabilidade ilimitada não eram considerados falidos, entretanto, o tipo de responsabilidade que tinham para com a sociedade empresarial definia se o patrimônio pessoal desses integraria a massa falida para saldar as dívidas da então sociedade falida.

Sérgio Campinho defende que:

\footnotetext{
21“A lei exclui do direito falimentar alguns empresários. A exclusão é total ou absoluta, se a sociedade empresária nunca puder falir (empresas públicas, sociedades de economia mista e câmaras de compensação), e é parcial ou relativa, se não puder falir apenas em determinadas hipóteses (seguradoras, operadoras de planos privados de assistência à saúde e instituições financeiras)." COELHO, Fábio Ulhoa, Curso de Direito Comercial, 15ª edição, São Paulo, Saraiva, 2014.v. 3, p.259
} 


\begin{abstract}
"O fato de os sócios, com esse tipo de sociedade, ficarem sujeitos à eficácia resultante da decretação da falência da pessoa jurídica não pode alargar conceitos, para despersonalizar a sociedade, a fim de formalmente declará-los falidos de direito. Uma coisa é ser falido, outra coisa é ficar sujeito aos efeitos da falência." Segue nesse diapasão, "Nutrimos simpatia pela visão de limitar a decretação da falência aos sócios que encarnarem a qualidade de empresário. Para os demais, não haveria propriamente a decretação de suas falências pessoais, mas tão-somente a sujeição, fundamentalmente no âmbito patrimonial, aos mesmos efeitos jurídicos produzidos pela sentença em relação à sociedade. Essa interpretação encontra-se em plena sintonia coma regra do artigo $1^{\circ}$, da lei de Recuperação e Falência, que adota o sistema restritivo do instituto, erigindo como sujeitos passivos o empresário individual e a sociedade empresária."(Agravo de Instrumento $\mathrm{n}^{\circ} \mathrm{s}$ 521.791.4/2-00 e 553.068.4/2-00 do Tribunal de Justiça do Estado de São Paulo.)
\end{abstract}

Sem desmerecer todo o debate, Fábio Ulhoa Coelho considera a discussão insignificante, não pelo conceito jurídico, mas pelo pouco uso dos tipos societários em quea responsabilidade do sócio é ilimitada: "a lei operou uma mudança aparentemente significativa no trato da matéria, mas que, bem examinada, não tem nenhuma implicação prática de relevo", explicando que "a falta de implicação prática relevante reside no âmbito de incidência do preceito", que "diz respeito unicamente às sociedades em nome coletivo, comandita simples (em relação ao comanditado) e por ações (em relação ao acionista-diretor)", acrescentando que "apenas nesses tipos societários há sócios ilimitadamente responsáveis pelas obrigações da sociedade" e concluindo que "como esses tipos de sociedade são raramente utilizados hoje em dia, a profunda alteração que o dispositivo introduz acaba se limitando ao aspecto conceitual da questão".

\title{
3.2.Apuração da responsabilidade pessoal dos sócios de responsabilidades limitadas, controladores e administradores (ART.82)
}

\begin{abstract}
"Art. 82. A responsabilidade pessoal dos sócios de responsabilidade limitada, dos controladores e dos administradores da sociedade falida, estabelecida nas respectivas leis, será apurada no próprio juízo da falência, independentemente da realização do ativo e da prova da sua insuficiência para cobrir o passivo, observado o procedimento ordinário previsto no Código de Processo Civil.”(Lei de Responsabilidade Fiscal - LRF, 2000)
\end{abstract}

O dispositivo acima estabelece que, independentemente da realização do ativo e da insuficiência para cobrir o passivo, será apurada a responsabilidade pessoal dos sócios de responsabilidade limitada, administradores ou controladores da sociedade 
falida, sendo certo ainda que o procedimento correto para a apuração desta responsabilidade deverá ser o procedimento ordinário previsto no Código de Processo Civil.Isto significa dizer que em termos de ação de responsabilidade trata-se de uma ação autônoma distribuída no próprio juízo da falência, onde será verificada a incidência da responsabilidade pessoal dos sócios, controladores e administradores da sociedade falida.

Em tese, a responsabilização do sócio estaria limitada asua participação no capital social. Os administradores, por sua vez, são responsáveis por aqueles atos que extrapolem os limites de seus poderes. As regras que indicam os limites dessas responsabilidades constam do Código Civil e das legislações pertinentes a cada tipo societário. A análise dessa responsabilidade e o reconhecimento de sua existência serão realizados pelo juízo da falência, independente da realização do ativo e da prova de insuficiência patrimonial. A demanda com esse escopo seguirá o procedimento comum ordinário previsto no Código de Processo Civil.

Na verdade, a responsabilidade prevista no artigo 82 visa recompor o patrimônio social da sociedade falida. As hipóteses de cabimento da ação de responsabilidade perante os sócios podem ser divididas em dois gêneros:a) Responsabilidade Civil por Atos Ilícitos contrários à Lei ou ao ato constitutivo da sociedade;b) Responsabilidade pela não integralização do capital social subscrito.

Da mesma forma, os controladores e os administradores também são contemplados pelo dispositivo e eles deverão ter sua responsabilidade pessoal pelos atos em que infringiram a lei, o contrato ou estatuto, apurada pelo juízo falimentar.

A disposição que permite a efetiva apuração da responsabilidade dos sócios com responsabilidade limitada, administradores e controladores, está contida no parágrafo $2^{\circ}$ do art. 82, que confere ao juiz o poder de determinar a indisponibilidade dos bens dos réus da ação ordinária. O objetivo é coibir a prática, bastante comum, de os controladores da sociedade dela se retirarem a tempo de não presenciar sua falência, transferindo suas quotas ou ações para homens de palha, de modo a evitar os efeitos da declaração da quebra, na tentativa de fugir de sua responsabilidade pessoal. A regra será mais funcional que a previsão da antiga lei, que permitia o sequestro de bens, requerido pelo síndico (art. $6^{\circ}, \S$ único).

O limite temporal da indisponibilidade é o julgamento da ação de responsabilização. Para muitos autores não parece a melhor solução, visto que a 
indisponibilidade só deveria ser levantada com o pagamento da dívida apurada,ou, quando muito, no momento da penhora suficiente, liberando-se os demais bens constrangidos.

A responsabilidade pessoal dos sócios, dos acionistas, dos controladores e dos administradores, nos termos das normas acima descritas, será sempre subjetiva. Daí a origem da norma do art. 82 da Lei $\mathrm{N}^{\circ}$. 11.101/05; sendo subjetiva, a responsabilidade terá de ser definida, dimensionada, enfim, apurada, na expressão da lei."

Nesse sentido, oportuno citar trecho do voto No. 14.933 do ilustre Professor e Desembargador, Manoel Pereira Calças, no Agravo de Instrumento No. 563.612.4/4-00, quando faz referência a Carlos Klein Zanini, in verbis:

"CARLOS KLEIN ZANINI, ao comentar o artigo 82 da LRF, é preciso na delimitação dos tipos de responsabilidade que deverão ser objeto de ação autônoma: "O cotejo entre o atual dispositivo e o antecedente põe em evidência, inicialmente, o tratamento conjunto - em um único artigo dispensado pela Lei a duas hipóteses distintas de responsabilidade: (i) a decorrente da prática de ato ilícito; e (ii) a decorrente do descumprimento da obrigação de integralização do saldo de capital social subscrito e nãointegralizado nas sociedades de responsabilidade limitada, aqui abrangidas tanto as sociedades limitadas quanto as anônimas." (Comentários à Lei de Recuperação de Empresas e Falência, Coordenadores: Francisco Satiro de Souza Jr. E Antônio Sérgio A. de Moraes Pitombo, Ed. RT, $2^{\text {a }}$ edição, p.354)."

\subsection{Extensão dos efeitos da falência a outras sociedades}

Além da desconsideração da personalidade jurídica para a responsabilização do patrimônio dos sócios e administradores, é possível a aplicação do art. 50 do Código Civil para que a decisão judicial estabeleça a responsabilidade de outras sociedades empresárias pelas obrigações assumidas por uma.

A Câmara Especial de Falências e Recuperações Judiciais do Tribunal de Justiça de São Paulo perfilha o entendimento de que, quando presentes os requisitos do artigo $50^{22}$, do Código Civil, a declaração da desconsideração da personalidade jurídica de sociedade empresária falida tem como objetivo a extensão dos efeitos da falência às

\footnotetext{
${ }^{22}$ Art. 50. Em caso de abuso da personalidade jurídica, caracterizado pelo desvio de finalidade, ou pela confusão patrimonial, pode o juiz decidir, a requerimento da parte, ou do Ministério Público, quando lhe couber intervir no processo, que os efeitos de certas e determinadas relações de obrigações sejam estendidos aos bens particulares dos administradores ou sócios da pessoa jurídica.
} 
sociedades integrantes do mesmo grupo econômico, notadamente quando constituída pelos mesmos sócios, especialmente se ligados por laços familiares.

A extensão dos efeitos da falência é construção jurisprudencial que visa estender os efeitos da declaração de falência às demais empresas do grupo de empresas, quando verificada a existência dos pressupostos do art. 50 do Código Civil durante o processo falimentar: desvio de finalidade ou confusão patrimonial entre as sociedades empresárias.Visa, primordialmente, buscar ativos desviados, como comumente ocorre em situações de confusão patrimonial ou desvio de finalidade, ultimadas com o fito de fraudar credores.

Inobstante o que dispõe a legislação sobre o tema, o Superior Tribunal de Justiça (STJ) tem entendido que é possível a extensão dos efeitos de sociedade falida a sociedades do mesmo grupo ou com estreito vínculo de interesses através da aplicação da Teoria da Desconsideração da Personalidade Jurídica sempre que restar verificada a utilização da empresa, com abuso de direito, para fraudar a lei ou prejudicar terceiros.

Tem entendido, ainda, que tal desconsideração prescinde de procedimento autônomo, podendo ser deferido nos próprios autos da falência, mediante requerimento da parte interessada.

Nesse sentido, cite-se o acórdão proferido pela Terceira Turma do Superior Tribunal de Justiça no Recurso Especial n ${ }^{\circ}$ 1259018/SP, julgado em 2011, sob a relatoria da Ministra Nancy Andrighi:

PROCESSO CIVIL. FALÊNCIA. EXTENSÃO DE EFEITOS. SOCIEDADES COLIGADAS. POSSIBILIDADE. AÇÃO AUTÔNOMA. DESNECESSIDADE. DECISÃO INAUDITA ALTERA PARTE. VIABILIDADE. RECURSO IMPROVIDO.

1. Em situação na qual dois grupos econômicos, unidos em torno de um propósitocomum, promovem uma cadeia de negócios formalmente lícitos, mas com intuitosubstancial de desviar patrimônio de empresa em situação pré-falimentar, é necessário que o Poder Judiciário também inove sua atuação, no intuito de encontrar meios eficazes de reverter as manobras lesivas, punindo e responsabilizando os envolvidos.

2. É possível ao juízo antecipar a decisão de estender os efeitos de sociedade falida a empresas coligadas na hipótese em que, verificando claro conluio para prejudicar credores, há transferência de bens para desvio patrimonial. Inexiste nulidade no exercício diferido do direito de defesa nessas hipóteses.

3. A extensão da falência a sociedades coligadas pode ser feita independentemente da instauração de processo autônomo. A verificação da existência de coligação entre sociedades pode ser feita com base em elementos fáticos que demonstrem a efetiva influência de um grupo societário nas decisões do outro, independentemente de se constatar a existência de participação no capital social. 
4. Na hipótese de fraude para desvio de patrimônio de sociedade falida, em prejuízo da massa de credores, perpetrada mediante a utilização de complexas formas societárias, é possível utilizar a técnica da desconsideração da personalidade jurídica com nova roupagem, de modo a atingir o patrimônio de todos os envolvidos.

5. Recurso especial não provido.

A jurisprudência tem aplicado, portanto, a técnica da desconsideração da personalidade jurídica não apenas para atingir o patrimônio das sociedades pertencentes ao grupo em virtude da prática de atos que importem no desvio patrimonial da sociedade em estado pré-falimentar, mas tem estendido os efeitos da falência às demais sociedades do grupo, tenham ou não participação societária na falida.

\section{ASPECTOS PROCESSUAIS - NOVO CÓDIGO DE PROCESSO CIVIL}

O Novo Código de Processo Civil, Lei 13.105 de 16 de março de 2015, em seus artigos 133 a 137 instituiu uma nova modalidade de intervenção de terceiros, qual seja, o incidente de desconsideração da personalidade jurídica.

Anterior à vigência do novo Código de Processo Civil, muitos doutrinadores defendiam a indispensabilidade da propositura de ação própria para que as responsabilidades da pessoa jurídica fossem atribuídas ao sócios. Nesse diapasão, Fábio Ulhoa Coelho esclarecia que o juiz não poderia desconsiderar a separação entre a pessoa jurídica e seus integrantes, senão por meio de ação judicial própria, de caráter cognitivo, movida pelo credor da sociedade contra os sócios ou seus controladores"23.

Tal entendimento, porém, foi sendo diversificado pela jurisprudência, admitindo a aplicação da desconsideração da personalidade jurídica sem a necessidade de ação autônoma. Ademais, não se mostra plausível suspender a execução já em curso contra a pessoa jurídica, pela não localização de bens passíveis de penhora em seu nome, para então ajuizar novo processo paralelo e autônomo de desconsideração, a fim de, tãosomente, obter título executivo judicial contra os sócios e declaração de ineficácia do ato ilícito praticado. Nesse caso, a constrição dos bens dos responsáveis ocorreria somente após o trânsito em julgado da referida ação de conhecimento, o que acabaria por retardar demasiadamente a efetivação do direito pretendido, ou, até mesmo, torná-la impossível.

\footnotetext{
${ }^{23}$ Coelho, Fábio Ulhoa. Curso de direito comercial. v. II. 5. ed. São Paulo, Saraiva, 2002. p. 54.
} 
Esse também é o entendimento do Superior Tribunal de Justiça:

“A aplicação da teoria da desconsideração da personalidade jurídica dispensa
a propositura de ação autônoma para tal. Verificados os pressupostos de sua
incidência, poderá o Juiz, incidentemente no próprio processo de execução
(singular ou coletiva), levantar o véu da personalidade jurídica para que o ato
de expropriação atinja os bens particulares de seus sócios, de forma a impedir
a concretização de fraude à lei ou contra terceiros." (STJ, Recurso Ordinário
MS no 16.274 - SP, Relatora Ministra Nancy Andrighi, julgado em 19 de
agosto de 2003).

Os adeptos desse entendimento acreditam que a desconsideração da pessoa jurídica, no próprio processo de execução, garantiria a celeridade do processo, e mais, o fato de a análise de cabimento ocorrer incidentalmente não viola os princípios constitucionais do contraditório e da ampla defesa, pois os sócios e os terceiros interessados, poderão se manifestar em momento posterior.

Como resultado da evolução jurisprudencial, o novo CPC criou um capítulo específico para tratar do "Incidente de Desconsideração da Personalidade Jurídica" (Título III, Capítulo IV), elencando-o como uma nova modalidade de intervenção de terceiros e colocando fim na discussão sobre a necessidade ou não da propositura de ação judicial própria, bastando o requerimento da parte ou do Ministério Público vedando ao juiz a determinação e ofício:

Art. 133. O incidente de desconsideração da personalidade jurídica será instaurado a pedido da parte ou do Ministério Público, quando lhe couber intervir no processo.(CPC, 2015)

O incidente possui a finalidade de atingir o patrimônio da pessoa física que se empenhar a utilizar-se da pessoa jurídica, da qual faz parte, como sócio, para prejudicar credores, ou seja, quando, a pessoa jurídica devedora não apresentar patrimônio suficiente para pagamento da dívida, com indícios de abuso da personalidade jurídica, existe então a possibilidade de o credor atacar os bens do sócio, através da desconsideração da personalidade jurídica.

Nesse diapasão, para garantir os princípios constitucionais do contraditório e da ampla defesa, osócio será citado para se manifestar no prazo de 15 dias (agora, úteis). Uma vez decorrido o prazo de manifestação da parte, caberá ao magistrado resolver a questão, por meio de decisão interlocutória,sendo o agravo de instrumento o recurso cabível contra referida decisão. 
É importante destacar que se trata de decisão exclusiva e específica para o processo em discussão, para quitação de eventual dívida,sendo que a pessoa jurídica, em regra, continua a existir no mundo jurídico.

\section{CONCLUSÃO}

Concluímos que a desconsideração da pessoa jurídica na falência estabelece ruptura com o princípioda separação entre os patrimônios dos sócios e da sociedade. A questão da inadmissibilidade ou não da desconsideração nos processos falimentares após a vigência da Lei n. 11.101/2005 está longe de ser pacificada.

Verifica-se que a aplicação da desconsideração da personalidade jurídicaé admitida, a fim de permitir a arrecadação de determinados bens desviados de formafraudulenta da sociedade falida, bem como, nos casos em que a confusão patrimonialnão permite a distinção dos bens particulares dos sócios com os bens da sociedade falida.

Os Tribunais pátrios têm aplicado a teoria da desconsideração da personalidade jurídica no processo falimentar, com o objetivo de estender as consequências da quebra aos sócios, sempre que restarem comprovados atos fraudulentos e desvios de bens com a finalidade de prejudicar os credores. Para que os sócios sejam responsabilizados, deve haver respeito ao devido processo legal, previsto em nossa Constituição. ${ }^{24}$

Para não haver dúvidas, reiteramos que a Lei $\mathrm{n}^{\circ}$ 11.101/2005autoriza a desconsideração da personalidade jurídica no seu artigo 82.

A desconsideração da personalidade jurídica é, sem dúvida, uma situação excepcional que permite ao credor, prejudicado por atos fraudatórios ou abusivos, pleitear asolvência de seu credito perante o sócio da pessoa jurídica devedora. Com isso, podemos perceber que o princípio do par conditio creditorumé mantido.

Todavia, apesar da ampla aplicação da desconstituição da personalidade jurídica na falência, cabe salientar o que prega CalixtoSalomãoFilho,que a desconsideração da personalidade jurídica e falência sãoconceitos antinômicos, porque a primeira é "método

\footnotetext{
${ }^{24}$ PAIVA, Luiz Fernando Valente de. (coord). Direito falimentar e a nova lei de falências e recuperação de empresas. São Paulo: QuartierLatin, 2005. p. 391
} 
para permitir exatamente acontinuação da atividade social" 25 , conforme posicionamento do STJ noAgRgEREsp 86.502-SP, explicando o autor que:

"A consequência da subordinação da desconsideração à insolvência seria aimposição aos credores de uma difícil escolha: a tentativa de receber seucrédito excluiria necessariamente a continuação da sociedade e das relaçõescomerciais." (SALOMÃO FILHO, 1995)

A adoção do princípio da limitação da responsabilidade das pessoas jurídicas é, antes de tudo, uma ferramenta para o estímulo ao empreendedorismo, visto que, ao fazêlo,eles reconhecem a importância da atuação dos particulares na economia, assegurando-lhe garantias contra os riscos do negócio, propiciando a toda a coletividade os benefícios advindos da atuação do empresário. A história nos mostra que foram os princípios da separação patrimonial e da limitação de responsabilidades, inerentes à personificação societária, que acabaram por canalizar os recursos necessários ao desenvolvimento da economia, evitando o desvirtuamento do investimento para atividades não produtivas.

\section{BIBLIOGRAFIA}

COELHO, Fábio Ulhoa.Curso de Direito Comercial,.vol. 3, 15 ed.ição, São Paulo, Saraiva, 2014.

COELHO, Fabio Ulhoa,.Curso de Direito Comercial.Vv.2.Saraiva, São Paulo, 2014.

COELHO, Fábio Ulhoa,.Manual de Direito Comercial,. 26 ed.ição, São Paulo, Saraiva, 2014.

COELHO, Fábio Ulhoa. O empresário e os direitos do consumidor. São Paulo:, Saraiva,1994.

MARTINS, F.Curso deDireito Comercial.RiodeJaneiro,Forense, 2010.

OLIVEIRA, José Lamartine Corrêa de. A dupla crise da pessoa jurídica. São Paulo,Saraiva, 1979.

PAIVA, Luiz Fernando Valente de. (coord). Direito falimentar e a nova lei de falências e recuperação de empresas. São Paulo:,QuartierLatin, 2005.

PAIVA, Luiz Fernando Valente de. (coord). Direito falimentar e a nova lei de falências e recuperação de empresas. São Paulo:,QuartierLatin, 2005.

${ }^{25}$ OLIVEIRA, José Lamartine Corrêa de. A dupla crise da pessoa jurídica, São Paulo, Saraiva, 1979.

http://revistasapereaude.org/index.php/edicoes/ano-5-volume-1-agosto-2016

D.O.I: 10.20523/sapereaude-ano5-vol-1-pg-77-95 
PEREIRA, Caio Mário da Silva. Instituições de Direito Civil,.vol. I. 19ª Eed. Forense. Rio de Janeiro. 2000. p. 185.

REQUIÃO, Rubens,.Curso de Direito Comercial,.1v. 1olume, São Paulo, Saraiva, 2014.

REQUIÃO, Rubens. Curso de Direito Comercial. São Paulo, Forense, 1998.

SALOMÃO FILHO, Calixto. A sociedade unipessoal. São Paulo: Malheiros, 1995. p. 90

SCARPINELla BUENO, Cassio, Novo Código de Processo Civil Anotado, Saraiva, São Paulo, 2015. (Comentários aos artigos 133 a 137).

TEPEDINO, Gustavo (Coord.). Problemas de Direito Civil-Constitucional. Rio de Janeiro:, Renovar, 2000. 